D) Check for updates

Cite this: Dalton Trans., 2018, 47 8003

\section{Acetylacetonato-based pincer-type nickel(II) complexes: synthesis and catalysis in cross- couplings of aryl chlorides with aryl Grignard reagents $\dagger$}

\author{
Erika Asano, ${ }^{a}$ Yuki Hatayama, ${ }^{a}$ Nobutaka Kurisu, ${ }^{a}$ Atsufumi Ohtani, ${ }^{a}$ \\ Toru Hashimoto, (iD a Youji Kurihara, ${ }^{a}$ Kazuyoshi Ueda, (iD) a Shinji Ishihara, (iD b \\ Hirotaka Nagaoc and Yoshitaka Yamaguchi (iD *a
}

\begin{abstract}
In this work, three different types of acetylacetonato-based pincer-type nickel(॥) complexes (2) were prepared. Complex 2a possessed the tridentate ONN ligand, which was constructed by the condensation reaction of acetylacetone with $\mathrm{N}, \mathrm{N}$-diethylethylenediamine. Complex $\mathbf{2} \mathbf{b}$ contained the $\mathrm{PPh}_{2}$ donor group in contrast to the $\mathrm{NEt}_{2}$ group in $\mathbf{2 a}$, i.e., an ONP ligand framework. Complex $\mathbf{2 c}$ was composed of the NNN ligand, which was prepared by the reaction of 4-((2,4,6-trimethylphenyl)amino)pent-3-en-2-one with $\mathrm{N}, \mathrm{N}$-diethylethylenediamine. In addition to X-ray diffraction analysis, these complexes were characterized spectroscopically. Their catalytic activity for a cross-coupling reaction of aryl halides with aryl Grignard reagents was also evaluated. Among these complexes, $\mathbf{2} \mathbf{b}$ acted as an effective catalyst for the cross-coupling reaction using aryl chlorides as electrophiles. The electronic properties of these $\mathrm{Ni}($ II) complexes were investigated by cyclic voltammetry and density functional theory calculations.
\end{abstract}

Received 3rd April 2018

Accepted 25th May 2018

DOI: $10.1039 / \mathrm{c} 8 \mathrm{dt} 01295 \mathrm{~d}$

rsc.li/dalton received significant attention. ${ }^{3}$ In order to achieve the activation and smooth scission of the $\mathrm{C}-\mathrm{Cl}$ bond in an electrophile on the metal, ancillary ligands are often used to provide an appropriate steric and electronic environment around the metal center. Naturally, such ligands play an important role in determining the catalytic properties. To date, several effective ligand systems for cross-coupling reactions have been reported. In recent years, tridentate pincer-type complexes have generated a lot of interest because the pincer-type ligand stabilizes the metal complexes and its properties can be tuned to achieve the best reactivity of the complex. ${ }^{4,5}$ Consequently, extensive attention has been focused on the combination of pincer-type ligands with $\mathrm{Ni}^{5-14}$ which is one of the most attractive metals because of its significantly low cost as compared to precious metals such as palladium, rhodium, etc.

We have recently reported the synthesis of iron complexes bearing the tridentate $\beta$-aminoketonato ligand, ${ }^{15}$ which was easily prepared by the condensation reaction of acetylacetone with a primary amine tethering an additional donor unit. These iron complexes proved to be highly effective catalysts for the cross-coupling reaction of alkyl halides and aryl Grignard reagents ${ }^{16}$ and the atom-transfer radical polymerization reaction of styrenes. ${ }^{17}$ In order to elucidate both the generality and the availability of this type of ligands for constructing pincer-type complexes, novel Ni(II) complexes bearing $\beta$-aminoketonato- and $\beta$-diketiminato-based tridentate ligands 
were prepared. The cross-coupling reaction of aryl halides with aryl Grignard reagents was also investigated using these $\mathrm{Ni}$ (II) complexes as catalysts. It was found that the modifications of the ligand framework had a significant influence on the catalytic performance. In this paper, we have described the synthesis and structures of the pincer-type Ni(II) complexes and their application as catalysts for the cross-coupling reactions. Furthermore, the electronic properties of the Ni(II) complexes were estimated by cyclic voltammetry (CV) and density functional theory (DFT) calculations.

\section{Results and discussion}

\section{Synthesis and characterization}

The synthetic procedures for the acetylacetone-based tridentate pro-ligands $\mathbf{1 - H}$ are shown in Scheme $\mathbf{1}$. The pro-ligands $\mathbf{1 a}-\mathbf{H}^{16}$ and $\mathbf{1 b}-\mathbf{H}^{18}$ were prepared according to the literature reported method of a condensation reaction of acetylacetone with the appropriate primary amine tethering an additional donating group such as $\mathrm{NEt}_{2}$ or $\mathrm{PPh}_{2}$ in the presence of a catalytic amount of $\mathrm{H}_{2} \mathrm{SO}_{4}$ in toluene at reflux. Pro-ligand $\mathbf{1 c - H}$ was prepared by the reaction of 4 -((2,4,6-trimethylphenyl)amino) pent-3-en-2-one with $N, N$-diethylethylenediamine. The former compound was prepared by the condensation of acetylacetone with 2,4,6-trimethylaniline. Compound $\mathbf{1} \mathbf{c}-\mathbf{H}$ was isolated as a brown liquid in $72 \%$ yield. These compounds were characterized by NMR spectroscopy. In the ${ }^{1} \mathrm{H}$ NMR spectrum of $\mathbf{1 - H}$, the characteristic signals of the $\mathrm{N}-\mathrm{H}$ proton atom were downfield at $\sim 10-11 \mathrm{ppm}$.

Single crystals of $\mathbf{1 b}-\mathbf{H}$ were obtained by recrystallization from toluene/hexane and analyzed by X-ray diffraction. The ORTEP drawing of $\mathbf{1 b}-\mathbf{H}$ is shown in Fig. 1. The position of the hydrogen atom (H1) bonded to the nitrogen atom (N1) was

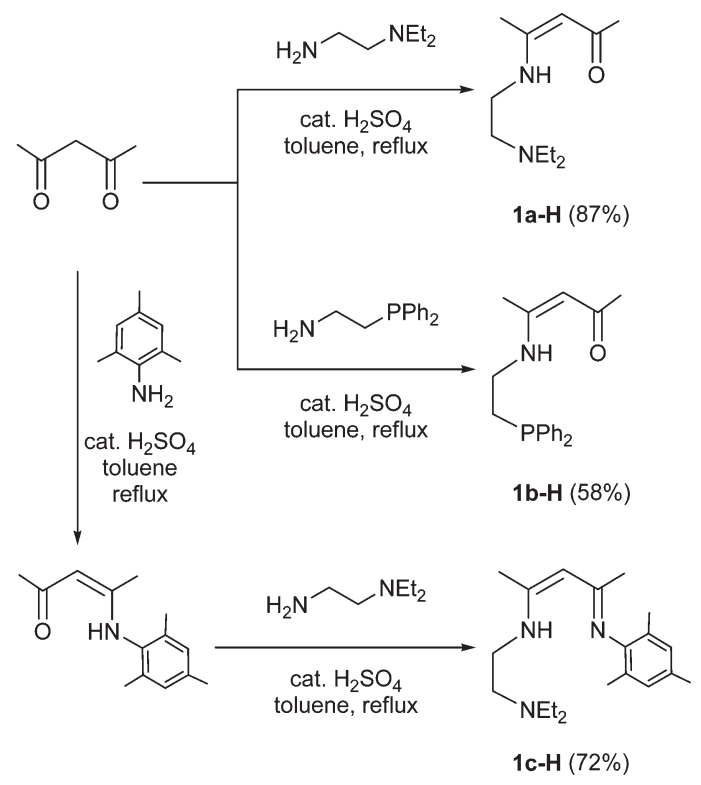

Scheme 1 Preparation of pro-ligands 1-H.

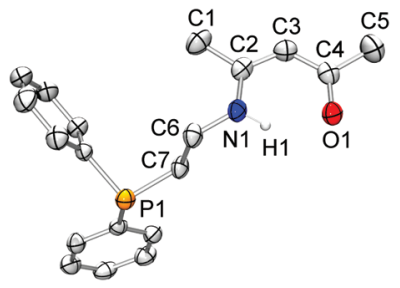

Fig. 1 ORTEP drawing of $1 \mathrm{~b}-\mathrm{H}$ (30\% probability of thermal ellipsoids). All hydrogen atoms except for $\mathrm{H} 1$ have been omitted for clarity. Selected bond lengths (Å) and angles ( $\left.{ }^{\circ}\right)$ : C1-C2, 1.507(4); C2-C3, 1.374(4); C3C4, 1.408(4); C4-C5, 1.511(4); O1-C4, 1.241(3); N1-C2, 1.324(4); N1$\mathrm{C} 6,1.454(3) ; \mathrm{N} 1-\mathrm{H} 1,0.90(3) ; \mathrm{N} 1 \ldots \mathrm{O} 1,2.687(3) ; \mathrm{O} 1 \ldots \mathrm{H} 1,1.94(4) ; \mathrm{N} 1-$ C2-C1, 117.7(2); N1-C2-C3, 122.3(2); C1-C2-C3, 120.0(3); C2-C3-C4, 124.5(3); O1-C4-C3， 123.2(2); O1-C4-C5, 118.5(3); C3-C4-C5, 118.3(3); C2-N1-C6， 127.4(2); C2-N1-H1， 112.3(15); C6-N1-H1， 119.8(15); N1-H1‥O1, 139(2).

determined from the difference Fourier maps and refined isotropically. The $\mathrm{N} 1 \cdots \mathrm{O} 1$ and $\mathrm{O} 1 \cdots \mathrm{H} 1$ distances were found to be 2.687(3) and 1.94(4) ̊, respectively. These distances are in good agreement with that of the reported $\mathrm{N}-\mathrm{H} \cdots \mathrm{O}$ hydrogen bond. ${ }^{19}$ In the $\beta$-aminoketone skeleton, the $\mathrm{N} 1-\mathrm{C} 2$ bond length $(1.324(4) \AA)$ is within the mean value of the $\mathrm{N}-\mathrm{C}$ single bond (1.48 $\AA$ ) and the $\mathrm{N}-\mathrm{C}$ double bond (1.24 $\mathrm{A}$ ). The O1-C4 bond length $(1.241(3) \AA)$ was close to the $\mathrm{C}-\mathrm{O}$ double bond

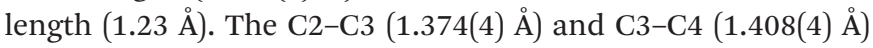
bond lengths were within the mean value of the $\mathrm{C}-\mathrm{C}$ single and double bond lengths. Although, the O1-C4 bond showed a slight double bond character, it is conceivable that the $\pi$-electrons on the $\mathrm{N} 1-\mathrm{C} 2-\mathrm{C} 3-\mathrm{C} 4-\mathrm{O} 1$ unit would be delocalized in this skeleton.

Next, the preparation of nickel(II) complexes 2 using these ligands was examined (Scheme 2). Treatment of the nickel(II)
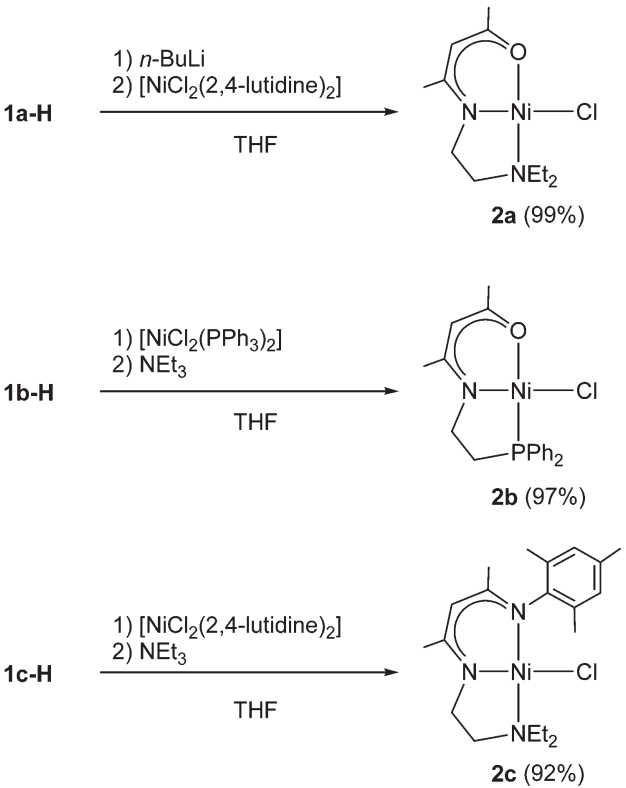

Scheme 2 Preparation of nickel complexes 2. 
complex precursor $\left[\mathrm{NiCl}_{2}(2,4 \text {-lutidine })_{2}\right]$ with the lithiated tridentate ligand (1a-Li), which was prepared in situ by the reaction of 1a-H with $n$-BuLi in THF, led to the formation of the $\mathbf{2 a}$ as a purple solid in 99\% yield. A similar procedure was used for the preparation of complex $2 \mathbf{b}$, i.e., the reaction of the lithiated ligand $\mathbf{1 b}-\mathbf{L i}$ with $\left[\mathrm{NiCl}_{2}(2,4 \text {-lutidine })_{2}\right]$. Complex $\mathbf{2 b}$ was isolated as an orange solid in moderate yield (70\%). We then examined the one-pot reaction of pro-ligand $\mathbf{1} \mathbf{b}-\mathbf{H}$ with $\left[\mathrm{NiCl}_{2}(2,4 \text {-lutidine })_{2}\right]$ in the presence of $\mathrm{NEt}_{3}$ as a base. In this case, $\mathbf{2 b}$ was obtained in $55 \%$ yield. The best yield of $\mathbf{2 b}(97 \%)$ was achieved by reacting $\left[\mathrm{NiCl}_{2}\left(\mathrm{PPh}_{3}\right)_{2}\right]$ as the metal precursor instead of $\left[\mathrm{NiCl}_{2}(2,4 \text {-lutidine })_{2}\right]$ with $\mathbf{1 b}-\mathbf{H}$ in the presence of $\mathrm{NEt}_{3}$. Complex 2c was isolated as a red solid in $40 \%$ yield from the reaction of the lithiated tridentate ligand $\mathbf{1 c}-\mathbf{L i}$ with $\left[\mathrm{NiCl}_{2}(2,4 \text {-lutidine })_{2}\right]$. In contrast, the one-pot reaction of $\mathbf{1 c -} \mathbf{H}$ with $\left[\mathrm{NiCl}_{2}(2,4 \text {-lutidine })_{2}\right]$ in the presence of $\mathrm{NEt}_{3}$ afforded complex 2c in $92 \%$ yield. Elemental analysis, NMR spectra, and X-ray diffraction studies confirmed the formation of the desired pincer-type Ni(II) complexes $\mathbf{2 a - 2 c}$.

In the ${ }^{1} \mathrm{H}$ NMR spectra of 2 , the low magnetic resonance assignable to the $\mathrm{N}-\mathrm{H}$ proton atom in pro-ligands $\mathbf{1}-\mathbf{H}$ was not

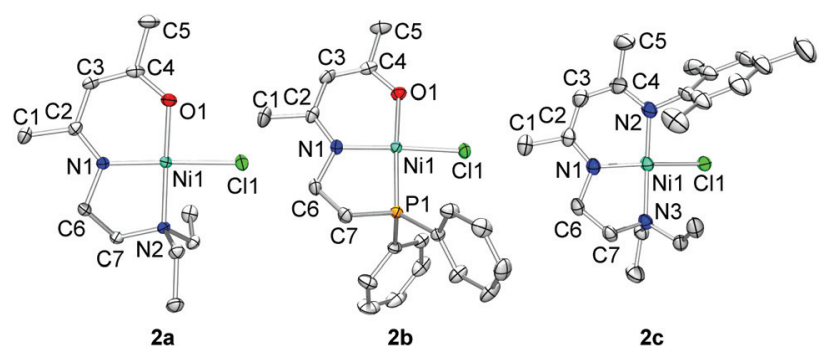

Fig. 2 ORTEP drawings of complexes $2 \mathrm{a}-2 \mathrm{c} \quad(30 \%$ probability of thermal ellipsoids). All hydrogen atoms have been omitted for clarity. observed. This indicated that the ligand $\mathbf{1}$ was deprotonated and coordinated to the nickel center as a monoanionic fashion. In complex $\mathbf{2 a}$, the methylene proton atoms of the diethylamino moiety showed two sets of doublet of quartets at 2.46 and $3.18 \mathrm{ppm}$ with coupling constants of 13.2 and $7.2 \mathrm{~Hz}$, respectively. The corresponding methylene proton atoms in the pro-ligand 1a-H showed a quartet at $2.57 \mathrm{ppm}$ with $J=7.3$ $\mathrm{Hz}$. The nonequivalence of these methylene proton atoms in complex $2 \mathrm{a}$ indicated that the ligand was coordinated to the $\mathrm{Ni}$ center in a tridentate fashion. Similar spectroscopic features were observed in complex 2c, namely, two sets of doublet of quartets corresponding to the methylene proton atoms in the diethylamino group at 2.40 and $3.25 \mathrm{ppm}$ with $J=12.8$ and 7.2 $\mathrm{Hz}$, respectively. Complex $\mathbf{2 b}$ was characterized by comparing the ${ }^{1} \mathrm{H}$ NMR and ${ }^{31} \mathrm{P}$-decoupled ${ }^{1} \mathrm{H}$ NMR $\left({ }^{1} \mathrm{H}\left\{{ }^{31} \mathrm{P}\right\} \quad\right.$ NMR $)$ spectra (see Experimental section). In the ${ }^{31} \mathrm{P}\left\{{ }^{1} \mathrm{H}\right\}$ NMR spectrum of $\mathbf{2 b}$, a singlet was observed at $37.5 \mathrm{ppm}$, which suggests that the $\mathrm{PPh}_{2}$ moiety was coordinated to the $\mathrm{Ni}$ center $(-20.8 \mathrm{ppm}$ for $\mathbf{1 b}-\mathbf{H})$. In the ${ }^{13} \mathrm{C}\left\{{ }^{1} \mathrm{H}\right\}$ NMR spectrum of $\mathbf{2 b}$, two doublet signals corresponding to the $\mathrm{OCCH}_{3}$ carbon atoms in the $\beta$-aminoketonato unit were observed at $178.8 \mathrm{ppm}(J=2.7 \mathrm{~Hz})$ and $25.2 \mathrm{ppm}(J=6.4 \mathrm{~Hz})$. These observations indicated that $\mathbf{1 b}$ was coordinated to the Ni center in a tridentate fashion and the phosphorus atom was positioned trans to the oxygen atom of the $\beta$-aminoketonato unit.

The structures of the nickel(II) complexes $2 \mathbf{a}, \mathbf{2 b}$ and $2 \mathbf{c}$ were determined by X-ray analysis. The ORTEP drawings of $2 \mathbf{a}$, 2b and $2 \mathbf{c}$ are shown in Fig. 2. The selected bond lengths and angles for these complexes are listed in Table 1. These complexes have a distorted square planar geometry around the central metal, in which the ligand coordinates in a tridentate pincer-type fashion. The angles for the ligands in the mutually cis position bound to the $\mathrm{Ni}$ center were in the range $86.08(10)-95.48(8)^{\circ}$ and the sum of the angles around the Ni

Table 1 Selected bond lengths $(\AA)$ and angles $\left(^{\circ}\right)$ of complexes $2 a, 2 b$ and $2 c$

\begin{tabular}{|c|c|c|c|c|c|}
\hline \multicolumn{2}{|l|}{$2 a$} & \multicolumn{2}{|l|}{$2 \mathbf{b}$} & \multicolumn{2}{|l|}{$2 c$} \\
\hline Ni1-N1 & $1.8696(18)$ & Ni1-N1 & $1.896(2)$ & Ni1-N1 & $1.860(2)$ \\
\hline $\mathrm{N} 1-\mathrm{C} 2$ & $1.316(3)$ & $\mathrm{N} 1-\mathrm{C} 2$ & $1.321(3)$ & $\mathrm{N} 1-\mathrm{C} 2$ & $1.321(4)$ \\
\hline $\mathrm{O} 1-\mathrm{C} 4$ & $1.296(3)$ & $\mathrm{O} 1-\mathrm{C} 4$ & $1.282(3)$ & $\mathrm{N} 2-\mathrm{C} 4$ & $1.339(4)$ \\
\hline $\mathrm{C} 1-\mathrm{C} 2$ & $1.511(4)$ & $\mathrm{C} 1-\mathrm{C} 2$ & $1.517(4)$ & $\mathrm{C} 1-\mathrm{C} 2$ & $1.504(5)$ \\
\hline $\mathrm{C} 4-\mathrm{C} 5$ & $1.506(4)$ & C4-C5 & $1.505(4)$ & $\mathrm{C} 4-\mathrm{C} 5$ & $1.527(5)$ \\
\hline Cl1-Ni1-N1 & $177.20(7)$ & Cl1-Ni1-N1 & $174.50(6)$ & Cl1-Ni1-N1 & $163.43(6)$ \\
\hline O1-Ni1-N2 & $178.36(9)$ & O1-Ni1-P1 & 174.16(5) & N2-Ni1-N3 & $169.29(9)$ \\
\hline N1-Ni1-O1 & $93.68(9)$ & N1-Ni1-O1 & $95.48(8)$ & N1-Ni1-N2 & $93.27(11)$ \\
\hline N1-Ni1-N2 & 87.11(9) & N1-Ni1-P1 & $88.10(6)$ & N1-Ni1-N3 & $86.08(10)$ \\
\hline Cl1-Ni1-O1 & $87.40(6)$ & Cl1-Ni1-O1 & $88.80(6)$ & Cl1-Ni1-N2 & $93.20(8)$ \\
\hline $\mathrm{C} 2-\mathrm{C} 3-\mathrm{C} 4$ & $123.9(2)$ & $\mathrm{C} 2-\mathrm{C} 3-\mathrm{C} 4$ & $125.9(2)$ & $\mathrm{C} 2-\mathrm{C} 3-\mathrm{C} 4$ & $125.8(3)$ \\
\hline Ni1-O1-C4 & $126.49(16)$ & Ni1-O1-C4 & $126.94(17)$ & Ni1-N2-C4 & $125.1(2)$ \\
\hline
\end{tabular}


center in complexes $\mathbf{2 a}$ and $\mathbf{2 b}$ was almost $360^{\circ}\left(359.93^{\circ}\right.$ for $\mathbf{2 a}$ and $360.30^{\circ}$ for $\mathbf{2 b}$ ). On the other hand, in complex $2 \mathbf{c}$, the sum of the angles around the $\mathrm{Ni}$ center was $362.89^{\circ}$. Furthermore, a notable feature was observed in the angles for the ligands in the mutually trans position bound to the $\mathrm{Ni}$ center. The Cl1-Ni1-N1 angles decreased in the order 2a $\left(177.20(7)^{\circ}\right)>2 b\left(174.50(6)^{\circ}\right)>2 c\left(163.43(6)^{\circ}\right)$. The other mutually trans ligand angles showed similar features $\left(\mathrm{O} 1-\mathrm{Ni1}-\mathrm{N} 2=178.36(9)^{\circ}\right.$ for $2 \mathrm{a}, \mathrm{O} 1-\mathrm{Ni1}-\mathrm{P} 1=174.16(5)^{\circ}$ for $\mathbf{2 b}$, and N2-Ni1-N3 = 169.29(9) ${ }^{\circ}$ for 2c). This trend may be explained by the presence of the sterically bulky substituent on the tridentate ligand. Therefore, it was assumed that the $\mathrm{Ni}$ center in complex $\mathbf{2 c}$ was sterically more crowded than in $\mathbf{2 a}$ and $2 \mathbf{b}$.

In all $\mathrm{Ni}(\mathrm{II})$ complexes, the $\mathrm{C} 2-\mathrm{C} 3$ and $\mathrm{C} 3-\mathrm{C} 4$ bond lengths were in almost the same ranges of 1.384(5)-1.408(3) $\AA$ and 1.366(4)-1.381(5) A, respectively. The N1-C2 bond lengths in all complexes and the N2-C4 bond length for $2 \mathrm{c}$ were within the mean value range of the $\mathrm{N}-\mathrm{C}$ single and double bonds. Furthermore, the $\mathrm{O} 1-\mathrm{C} 4$ bond lengths in $\mathbf{2 a}$ and $\mathbf{2} \mathbf{b}$ were within the mean value range of the $\mathrm{O}-\mathrm{C}$ single and double bonds. This implied that the $\pi$-electrons were delocalized on the N1-C2-C3-C4-O1 and N1-C2-C3-C4-N2 frameworks. The conjugated nitrogen atom $\mathrm{N} 1$ and the $\mathrm{Ni}$ center bond lengths

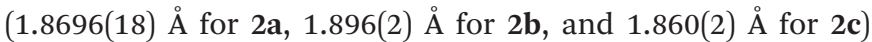
were substantially shorter than the amino nitrogen atom $\mathrm{N} 2$ or $\mathrm{N} 3$ and Ni bond lengths (Ni1-N2 = 1.980(2) $\AA$ for $2 \mathrm{a}$ and Ni1-N3 = 1.994(3) $\AA$ for 2c). Furthermore, the bond length of the other conjugated nitrogen atom N2 and Ni1 (1.891(3) A) in 2c was close to the Ni1-N1 bond length in complexes 2 . Therefore, it is conceivable that the monoanionic conjugated ligand system makes a considerable contribution to the formation of the stable pincer-type $\mathrm{Ni}$ (II) complexes.

\section{Cross-coupling reaction catalyzed by $\mathrm{Ni}$ (II) complexes}

The pincer-type Ni(II) complexes (2a-2c) were examined as catalysts in the cross-coupling reaction of 4-halotoluene with phenylmagnesium bromide. The results of the optimization experiments are summarized in Table 2.

In order to evaluate the catalytic activity of three nickel(II) complexes, the cross-coupling reaction was conducted by using $1.0 \mathrm{mmol}$ of 4 -chlorotoluene with 1.5 equivalents of phenylmagnesium bromide and $1 \mathrm{~mol} \%$ of the nickel(II) complex in THF at $25^{\circ} \mathrm{C}$ for $24 \mathrm{~h}$ (entries 1-3). It was found that these complexes exhibited catalytic activity in the cross-coupling reaction and that complex $\mathbf{2 b}$, which has the $\beta$-aminoketonato skeleton with a $\mathrm{PPh}_{2}$ moiety as the third donor, gave the best result. Complex 2b afforded 4-phenyltoluene (3) in 83\% yield along with the formation of homo-coupled products, biphenyl (4, $12 \%)$ and 4,4'-dimethylbiphenyl (5, 5\%). To investigate the influence of the halide in as electrophile, the catalytic reactions were performed with 4-bromotoluene and 4-iodotoluene in the presence of a catalytic amount of $\mathbf{2 b}$. Similar results were obtained in the case of 4-bromotoluene (entry 4). On the other hand, with 4-iodotoluene, the yield of the cross-coupled product 3 decreased to $52 \%$ and that of the homo-coupled product 4 derived from the nucleophile increased to $37 \%$ (entry 5). In this case, 4-iodotoluene would act as not only an electrophile but also an oxidizing agent for the nickel in the catalytic cycle. Therefore, it caused the decrease in the cross-coupled product and the increase in the homo-coupled product. These results show that complex $\mathbf{2 b}$ effectively catalyzed the cross-coupling reaction of aryl chloride as an electrophile. To further investigate the influence of the solvent, the reaction was conducted in different solvents. In ethereal solvents such as 1,2-dimethoxyethane (DME), $\mathrm{Et}_{2} \mathrm{O}$, and cyclopentyl methyl ether (CPME), poor

Table 2 Optimization of the cross-coupling reaction catalyzed by $\mathrm{Ni}\left(\right.$ II) complexes $2^{a}$

\begin{tabular}{|c|c|c|c|c|c|c|c|c|}
\hline & $1 \mathrm{mmol}-\mathrm{Me}+$ & $-\mathrm{MgBr}$ & $\begin{array}{l}\text { talyst } \\
\mathrm{nt} \\
24 \mathrm{~h}\end{array}$ & 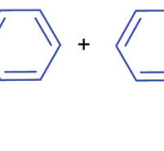 & & 1 & & \\
\hline Entry & Ni catalyst (mol\%) & $\mathrm{X}(p$-TolX $)$ & PhMgBr (equiv.) & Solvent & $T\left({ }^{\circ} \mathrm{C}\right)$ & $3^{b}(\%)$ & $4^{b}(\%)$ & $5^{b}(\%)$ \\
\hline 1 & $2 a(1)$ & $\mathrm{Cl}$ & 1.5 & $\mathrm{THF}$ & 25 & 47 & 23 & 18 \\
\hline 2 & $2 b(1)$ & $\mathrm{Cl}$ & 1.5 & $\mathrm{THF}$ & 25 & 83 & 12 & 5 \\
\hline 3 & $2 c(1)$ & $\mathrm{Cl}$ & 1.5 & THF & 25 & 48 & 25 & 18 \\
\hline 4 & $2 \mathbf{b}(1)$ & $\mathrm{Br}$ & 1.5 & THF & 25 & 80 & 13 & 6 \\
\hline 5 & $2 b(1)$ & I & 1.5 & THF & 25 & 52 & 37 & 5 \\
\hline 6 & $2 \mathbf{b}(1)$ & $\mathrm{Cl}$ & 1.5 & DME & 25 & 19 & 7 & 2 \\
\hline 7 & $2 \mathbf{b}(1)$ & $\mathrm{Cl}$ & 1.5 & $\mathrm{Et}_{2} \mathrm{O}$ & 25 & 19 & 13 & 1 \\
\hline 8 & $2 \mathbf{b}(1)$ & $\mathrm{Cl}$ & 1.5 & CPME & 25 & 48 & 15 & 4 \\
\hline 9 & $2 b(1)$ & $\mathrm{Cl}$ & 1.5 & 1,4-Dioxane & 25 & 73 & 11 & 4 \\
\hline 10 & $2 b(1)$ & $\mathrm{Cl}$ & 1.5 & toluene & 25 & 69 & 23 & 14 \\
\hline 11 & $2 \mathbf{b}(1)$ & $\mathrm{Cl}$ & 1.5 & THF & 50 & 84 & 17 & 9 \\
\hline 12 & $2 b(1)$ & $\mathrm{Cl}$ & 1.5 & THF & 0 & 74 & 9 & 4 \\
\hline 13 & $2 \mathbf{b}(1)$ & $\mathrm{Cl}$ & 2.0 & THF & 25 & 82 & 14 & 5 \\
\hline 14 & $2 \mathbf{b}(1)$ & $\mathrm{Cl}$ & 2.5 & THF & 25 & 84 & 10 & 7 \\
\hline 15 & $2 \mathbf{b}(2.5)$ & $\mathrm{Cl}$ & 1.5 & THF & 25 & 91 & 14 & 6 \\
\hline
\end{tabular}

${ }^{a}$ The reaction was carried out a $1.0 \mathrm{mmol}$ scale of 4-halotoluene. Phenylmagnesium bromide was added at once. ${ }^{b}$ The yields were determined by GLC analysis using octadecane as an internal standard. 
results were obtained (entries 6-8). In 1,4-dioxane, product 3 was obtained in $73 \%$ yield (entry 9). Toluene was also an effective solvent and the yield of 3 was $69 \%$ (entry 10). From these results, it was concluded that THF was a suitable solvent for this reaction. The reactions were conducted at $50{ }^{\circ} \mathrm{C}$ and $0{ }^{\circ} \mathrm{C}$. However, the yield of 3 was not improved at higher or lower temperatures (entries 11 and 12). Regarding the optimum amounts of the Grignard reagent and the catalyst $\mathbf{2 b}$, it was found that 1.5 equivalents of the Grignard reagent and $2.5 \mathrm{~mol} \%$ of the catalyst led to good yields of 3 (entries 13-15).

To demonstrate the efficiency of complex $\mathbf{2} \mathbf{b}$ as a catalyst for the biaryl cross-coupling reaction, we investigated the scope of the reaction by using different aryl chlorides and arylmagnesium bromides under the optimized reaction conditions. The results are summarized in Table 3. The aryl halide 4-chlorobenzotrifluoride, which has an electron-withdrawing group on the aromatic ring, afforded the desired product in $85 \%$ yield after $24 \mathrm{~h}$ (entry 1). Furthermore, the reaction was complete within 5 min (entry 2). In the case of 4 -chloroanisole, which has an electron-donating substituent, the product was obtained in $88 \%$ yield after $24 \mathrm{~h}$ (entry 3 ). However, after $5 \mathrm{~min}$, the yield of the product was only $35 \%$ (entry 4).
3-Chlorotoluene was effectively converted to 3-phenyltoluene ( $87 \%$, entry 5$)$. In the case of 2 -chlorotoluene, the coupled product, 2-phenyltoluene, was obtained in $67 \%$ yield under the optimized conditions $\left(25^{\circ} \mathrm{C}, 24 \mathrm{~h}\right.$, entry 6$)$. Under THFrefluxing conditions, the yield of 2-phenyltoluene increased to $81 \%$ (entry 7). Next, we examined the reaction of chlorobenzene with tolylmagnesium bromides. In the case of both $p$ and $m$-tolylmagnesium bromide, coupling products were formed in 91\% yield (entries 8 and 9). On treating with $o$-tolylmagnesium bromide at $25{ }^{\circ} \mathrm{C}, 2$-phenyltoluene was formed in $60 \%$ yield (entry 10). The product yield increased to $84 \%$ under refluxing conditions (entry 11). 2-Chloro-1,3,5-trimethylbenzene (mesityl chloride), as a sterically congested substrate, was examined in the reaction with phenylmagnesium bromide. When the reaction was conducted at $25^{\circ} \mathrm{C}$ for $72 \mathrm{~h}$, only a small amount of the desired product was obtained (5\%, entry 12). The product yield did not increase to any appreciable extent (16\%, entry 13$)$ even after reflux for $72 \mathrm{~h}$. In the reaction of chlorobenzene with 2-mesitylmagnesium bromide at $25{ }^{\circ} \mathrm{C}$ for $72 \mathrm{~h}$, the yield of the product was not improved (2\%, entry 14). On the other hand, the product was formed in $42 \%$ yield under refluxing conditions (entry 15).

Table 3 Results of cross-coupling reaction catalyzed by $2 \mathrm{~b}^{a}$

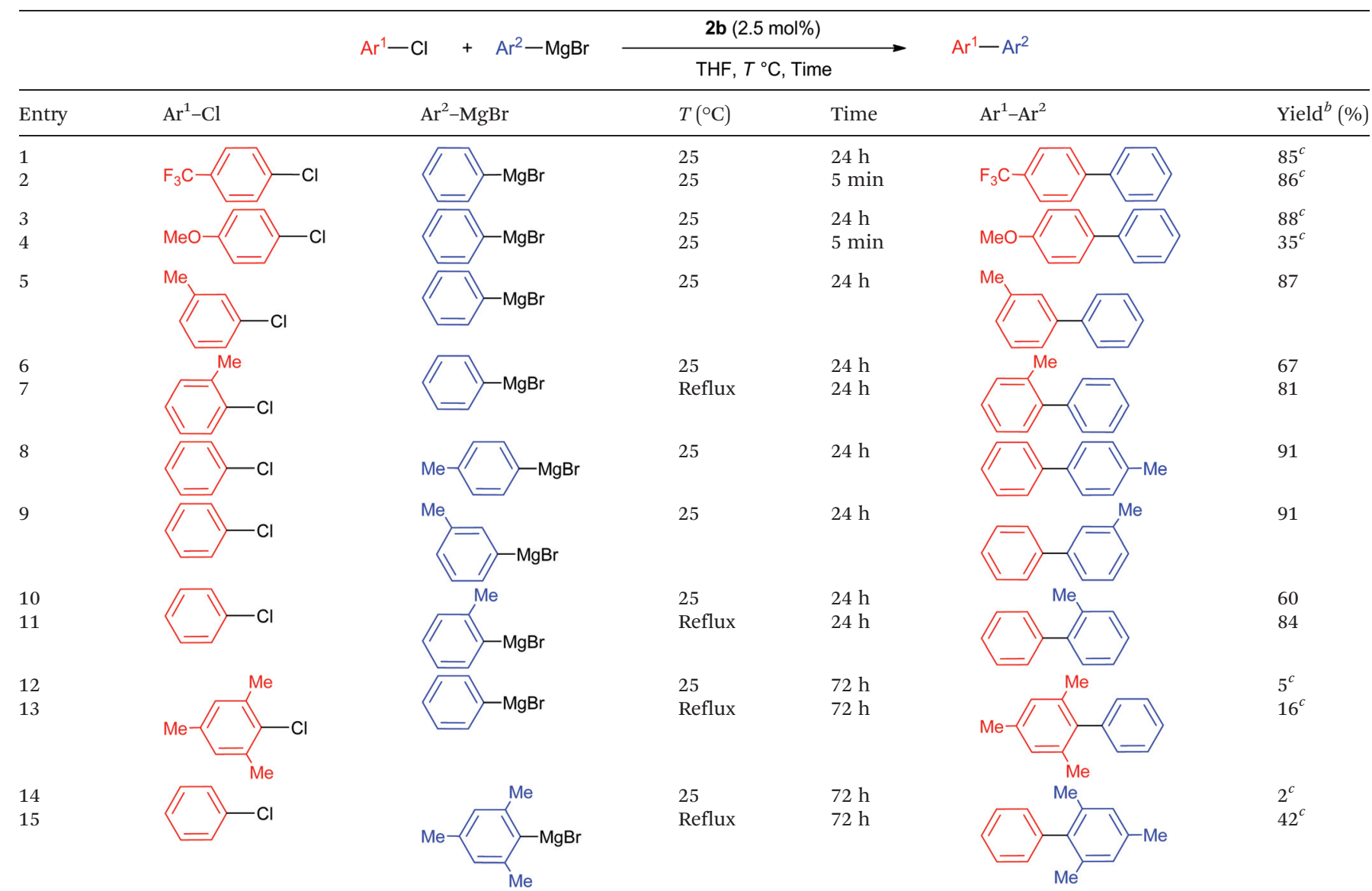

\footnotetext{
${ }^{a}$ The reaction was carried out with chloroarene $(1.0 \mathrm{mmol})$ and arylmagnesium bromide $(1.5 \mathrm{mmol})$ in the presence of the catalyst $2 \mathbf{b}(0.025 \mathrm{mmol})$. Arylmagnesium bromide was added at once. ${ }^{b}$ The yield was determined by GLC analysis using octadecane as an internal standard. ${ }^{c}$ The yield was determined by ${ }^{1} \mathrm{H}$ NMR analysis using pyrazine as an internal standard.
} 
Table 4 Results of cross-coupling reaction of dihalobenzene with $\mathrm{PhMgBr}^{a}$

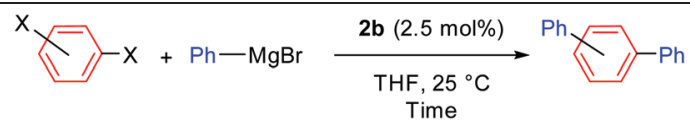

\begin{tabular}{|c|c|c|c|}
\hline Entry & Dihalobenzene & Time & Yield $^{b}(\%)$ \\
\hline 1 & & $5 \mathrm{~min}$ & $80\left(88^{c}\right)$ \\
\hline 2 & & $24 \mathrm{~h}$ & 67 \\
\hline 3 & & $24 \mathrm{~h}$ & 11 \\
\hline $\begin{array}{l}4 \\
5\end{array}$ & & $\begin{array}{l}5 \mathrm{~min} \\
24 \mathrm{~h}\end{array}$ & $\begin{array}{l}52 \\
62\end{array}$ \\
\hline
\end{tabular}

${ }^{a}$ The reaction was carried out with dihalobenzene $(1.0 \mathrm{mmol})$ and $\mathrm{PhMgBr}(2.5 \mathrm{mmol})$ in the presence of the catalyst $2 \mathbf{b}(0.025 \mathrm{mmol})$. $\mathrm{PhMgBr}$ was added at once. ${ }^{b}$ Isolated yield. ${ }^{c}$ The yield was determined by GLC analysis using octadecane as an internal standard.

Next, we examined the reaction of dihalobenzene with 2.5 equivalents of phenylmagnesium bromide and $2.5 \mathrm{~mol} \%$ of complex $\mathbf{2 b}$. The results are summarized in Table 4 . In the case of 1,4-dichlorobenzene, $p$-terphenyl was formed within 5 min in $88 \%$ yield, as determined by gas-liquid chromatography (GLC) analysis, and the product was isolated in $80 \%$ yield (entry 1 ). In the case of 1,3-dichlorobenzene, $m$-terphenyl was isolated in $67 \%$ yield (entry 2), whereas the yield of $o$-terphenyl decreased to $11 \%$ using 1,2-dichlorobenzene (entry 3 ). In contrast, the reaction with 1,4-dibromobenzene as an electrophile gave $p$-terphenyl in $52 \%$ yield after 5 min and $62 \%$ yield after $24 \mathrm{~h}$ (entries 4 and 5). These results clearly show that complex $\mathbf{2 b}$ can activate the $\mathrm{C}-\mathrm{Cl}$ bond, and more effectively than the $\mathrm{C}-\mathrm{Br}$ bond in the cross-coupling reaction.

\section{Catalytic performance of 2 for the KTC reaction}

As mentioned above, the three nickel(II) complexes (2) are catalytically active in the Kumada-Tamao-Corriu (KTC) reaction. Among these complexes, $\mathbf{2 b}$ possesses the $\beta$-aminoketonato framework with the $\mathrm{PPh}_{2}$ unit as the third donor and acts as an effective pre-catalyst for this reaction. In order to elucidate the catalytic performance of these complexes, the electronic properties of complexes 2 were estimated by CV. The cyclic voltammograms of these complexes were measured in a $\mathrm{CH}_{2} \mathrm{Cl}_{2}$ solution. All complexes exhibited irreversible oxidation waves, which are shown in Fig. S5 and S6 (ESI $\dagger$ ). The CV of complex 2b showed a one-electron oxidation wave at $0.61 \mathrm{~V} v s . \mathrm{Fc} / \mathrm{Fc}^{+}$. In the case of complex $2 \mathbf{a}$, a similar oxidation potential was seen at $0.64 \mathrm{~V}$. On the other hand, complex $2 \mathrm{c}$ showed a lower potential $(0.26 \mathrm{~V})$ than complexes $2 \mathbf{a}$ and $2 \mathbf{b}$. These oxidation potentials are reasonable values for the pincer-type Ni(II) complexes as compared to literature values, which were independently reported by Tonzetich ${ }^{12}$ and Zargarian. ${ }^{14 a}$ Based on the oxidation potentials of these complexes, it is conceivable that the electron density accumulated at the Ni center increases in the order $\mathbf{2 a} \approx \mathbf{2} \mathbf{b}<\mathbf{2} \mathbf{c}$. We assumed that the highest occupied molecular orbital (HOMO) levels of these complexes would also increase in this order. Therefore, the electronic properties of the series of $\mathrm{Ni}$ (II) complexes were investigated theoretically.

Computational study was carried out using Gaussian 09 at the B3LYP level with LANL2DZ basis set for the Ni atom and $6-311++\mathrm{G}(\mathrm{d}, \mathrm{p})$ for the other atoms. The LANL2DZ pseudopotential was used for the Ni center. Geometry optimizations of $\mathrm{Ni}$ (II) complexes $\mathbf{2 a}, \mathbf{2 b}$, and $\mathbf{2 c}$ were successful. The optimized molecular structures are shown in Fig. S7 (ESI $\dagger$ ). Selected geometrical parameters of these complexes are summarized in Table S6 (ESI $\dagger$ ). The geometrical parameters of the $\mathrm{Ni}$ (II) complexes determined by DFT were found to be in good agreement with those obtained from X-ray analysis, although the calculations predicted slightly longer bond lengths.

The plots of the HOMO and LUMO orbitals of complexes 2a-2c are illustrated in Fig. S8 (ESI $\dagger$ ). These complexes had similar HOMO and LUMO orbitals. The HOMO of $2 \mathrm{a}(-5.68$ $\mathrm{eV})$ was similar to that of $\mathbf{2 b}(-5.61 \mathrm{eV})$ in energy, while the energy level of $2 \mathrm{c}(-5.23 \mathrm{eV})$ was obviously higher than those of $2 \mathbf{a}$ and $\mathbf{2 b}$. Furthermore, in these Ni(II) complexes, there was a good relationship between the HOMO energies and oxidation potentials determined by cyclic voltammetry. In these $\mathrm{Ni}$ (II) complexes, the HOMO orbitals are mainly located on the sixmembered ring consisting of $\mathrm{Ni}$ and the conjugated ligand framework. Therefore, it was assumed that the conjugated ligand had an electronic influence on the Ni center and that the Ni(II) complex 2c was more electron rich as comparted to $\mathbf{2 a}$ and $\mathbf{2 b}$. In general, it is known that in an electron rich metal complex, the oxidative addition reaction of an electrophile to the metal takes place quite easily. ${ }^{20}$ Therefore, it was expected that complex 2c would exhibit a high catalytic performance in the cross-coupling reactions. However, as mentioned above, the catalytic performance of complex $\mathbf{2 b}$ was superior to that of $\mathbf{2 a}$ and $2 \mathbf{c}$. Although, further investigation of the influence of electronic factors on the catalytic activity is necessary, the steric environment around the Ni center should be considered as the most dominant factor affecting the catalytic performance. The X-ray diffraction study of the series of $\mathrm{Ni}$ (II) complexes revealed that complex 2c was more distorted from the ideal square planar geometry around the Ni center compared to complexes $\mathbf{2 a}$ and $\mathbf{2 b}$ (vide supra). This distortion arises from the steric bulkiness of the ligand skeleton. Therefore, in complex $2 \mathbf{c}$, the interaction of the substrate with the $\mathrm{Ni}$ center is encumbered and leads to poor catalytic activity. Compared to complex $\mathbf{2 b}$, complex $2 \mathbf{a}$ also shows lower activity. These complexes show similar electronic features, as estimated by CV and DFT. The low performance of $2 \mathrm{a}$ might be attributed to the different "third donor", i.e., the phosphorus or nitrogen donor atoms. Phosphorus as the third donor in complex $\mathbf{2 b}$ would elicit a higher performance in the cross-coupling reaction. Further investigations of the influence of the ligand framework on the catalytic performance are currently underway. 


\section{Conclusions}

In this work, we investigated the synthesis of pincer-type $\mathrm{Ni}$ (II) complexes and their catalytic performance for the KTC reaction. $\beta$-Aminoketonato and $\beta$-diketiminato frameworks tethering the nitrogen or phosphorus groups as the third donor to the metal center led to the desired pincer-type Ni(II) complexes 2. The Ni(II) complexes exhibited catalytic activity for the KTC reaction; complex $\mathbf{2 b}$ bearing the $\beta$-aminoketonato framework with the diphenylphosphino group as the third donor showed remarkable catalytic performance. The combination of $\beta$-aminoketonato and/or $\beta$-diketiminato frameworks with the third donor enabled the fine tuning of the electronic and steric factors around the metal center. These pincer ligand systems can be easily prepared by the condensation reaction of acetylacetone with amines and their coordination to various transition metals is expected to produce highly active metal catalysts. Further investigations on the mechanistic aspects, the coupling reactions of various organometallic reagents with organic electrophiles, and the application of these ligand systems to other metals are currently underway.

\section{Experimental}

\section{General procedures}

All manipulations involving air- and moisture-sensitive organometallic compounds were performed under an atmosphere of nitrogen, which was dried with SICAPENT (Merck Co., Inc.), using standard Schlenk tube or high vacuum techniques. All solvents were distilled over appropriate drying agents prior to use. 2-(Diphenylphosphino)ethylamine, ${ }^{21} \mathbf{1 a}-\mathbf{H},{ }^{16} \mathbf{1 b}-\mathbf{H},{ }^{18}$ 4-((2,4,6-trimethylphenyl)amino)pent-3-en-2-one, ${ }^{22} \quad\left[\mathrm{NiCl}_{2}(2,4-\right.$ lutidine $\left.)_{2}\right],{ }^{23}$ and $\left[\mathrm{NiCl}_{2}\left(\mathrm{PPh}_{3}\right)_{2}\right]^{24}$ were prepared according to literature reported procedures. The other reagents employed in this work were commercially available and used without further purification. ${ }^{1} \mathrm{H},{ }^{1} \mathrm{H}\left\{{ }^{31} \mathrm{P}\right\},{ }^{13} \mathrm{C}\left\{{ }^{1} \mathrm{H}\right\}$, and ${ }^{31} \mathrm{P}\left\{{ }^{1} \mathrm{H}\right\}$ NMR spectra were recorded on BRUKER DRX-300, DRX-500, or JEOL ECX-400 spectrometers at ambient temperature. The ${ }^{1} \mathrm{H},{ }^{1} \mathrm{H}$ $\left\{{ }^{31} \mathrm{P}\right\}$, and ${ }^{13} \mathrm{C}\left\{{ }^{1} \mathrm{H}\right\}$ NMR chemical shifts were recorded in ppm relative to $\mathrm{Me}_{4} \mathrm{Si}$ as an internal standard. The ${ }^{31} \mathrm{P}\left\{{ }^{1} \mathrm{H}\right\}$ NMR chemical shifts were recorded in ppm relative to $\mathrm{H}_{3} \mathrm{PO}_{4}$ as an external standard. All coupling constants were recorded in $\mathrm{Hz}$. Multiplicity is indicated by s (singlet), $\mathrm{d}$ (doublet), $\mathrm{t}$ (triplet), $\mathrm{q}$ (quartet), dt (doublet of triplets), dq (doublet of quartets) and $\mathrm{m}$ (multiplet). Thin layer chromatography was performed using Merck silica gel 60F-254 plates and examined under UV $(254 \mathrm{~nm})$ irradiation. Column chromatography was performed using Silica Gel 60N (spherical, neutral, 63-210 $\mu \mathrm{m}$, Kanto Chemical Co., Inc.). High-resolution mass spectra (HRMS) were recorded using fast atom bombardment (FAB) ionization with a JEOL JMS-700 mass spectrometer. Elemental analyses were performed on a Vario EL elemental analyzer. GLC were recorded on a Shimadzu GC-17A gas chromatograph using a ULBON HR-1 capillary column $(0.25$ ID $\times 25 \mathrm{~m}$, Shinwa Chemical Industries Ltd).

\section{Preparation of 1c-H}

4-((2,4,6-Trimethylphenyl)amino)pent-3-en-2-one $\quad(1240 \mathrm{mg}$, $5.71 \mathrm{mmol}), N, N$-diethylethylenediamine $(992 \mathrm{mg}, 1.20 \mathrm{~mL}$, $8.54 \mathrm{mmol})$, and toluene $(60 \mathrm{~mL})$ were put in a round-bottom flask. A few drops of $\mathrm{H}_{2} \mathrm{SO}_{4}$ and molecular sieves $4 \AA$ ( $c a .10 \mathrm{~g}$ ) were added to the reaction mixture. The mixture was refluxed for $48 \mathrm{~h}$ and then cooled to room temperature. After neutralization with aq. $\mathrm{KOH}$, the reaction mixture was extracted with $\mathrm{CH}_{2} \mathrm{Cl}_{2}$. The combined organic extracts were dried with $\mathrm{Na}_{2} \mathrm{SO}_{4}$, filtered, and concentrated in vacuo to obtain $\mathbf{1 c}-\mathbf{H}$ as a brown liquid (1300 mg, $4.12 \mathrm{mmol}, 72 \%) .{ }^{1} \mathrm{H} \mathrm{NMR}\left(\delta, \mathrm{CDCl}_{3}\right)$ : $0.97\left(\mathrm{t}, J=7.3 \mathrm{~Hz}, 6 \mathrm{H}, \mathrm{NCH}_{2} \mathrm{CH}_{3}\right), 1.59\left(\mathrm{~s}, 3 \mathrm{H}, \mathrm{NCCH}_{3}\right), 2.00(\mathrm{~s}$, $9 \mathrm{H}, o-\left(\mathrm{CH}_{3}\right) \mathrm{C}_{6} \mathrm{H}_{2}+p-\left(\mathrm{CH}_{3}\right) \mathrm{C}_{6} \mathrm{H}_{2}$, overlapped), 2.26 (s, $3 \mathrm{H}$, $\left.\mathrm{NCCH}_{3}\right), 2.51$ (q, $\left.J=7.3 \mathrm{~Hz}, 4 \mathrm{H}, \mathrm{NCH}_{2} \mathrm{CH}_{3}\right), 2.54(\mathrm{~m}, 2 \mathrm{H}$, $\left.\mathrm{NCH}_{2} \mathrm{CH}_{2} \mathrm{~N}\right), 3.30\left(\mathrm{~m}, 2 \mathrm{H}, \mathrm{NCH}_{2} \mathrm{CH}_{2} \mathrm{~N}\right), 4.62(\mathrm{~s}, 1 \mathrm{H}, \mathrm{CH}), 6.84$ (s, $\left.2 \mathrm{H}, \mathrm{N}-m-\left(\mathrm{CH}_{3}\right)_{3} \mathrm{C}_{6} \mathrm{H}_{2}\right), 10.69$ (broad s, $\left.1 \mathrm{H}, \mathrm{NH}\right) \cdot{ }^{13} \mathrm{C}\left\{{ }^{1} \mathrm{H}\right\}$ $\operatorname{NMR}\left(\delta, \mathrm{CDCl}_{3}\right): 11.9\left(\mathrm{~s}, \mathrm{NCH}_{2} \mathrm{CH}_{3}\right), 18.3\left(\mathrm{~s}, \mathrm{~N}-\mathrm{o}-\left(\mathrm{CH}_{3}\right)_{3} \mathrm{C}_{6} \mathrm{H}_{2}\right)$, 19.4 (s, N-p-( $\left.\left(\mathrm{H}_{3}\right)_{3} \mathrm{C}_{6} \mathrm{H}_{2}\right), 20.7$ (s, $\left.\mathrm{NCCH}_{3}\right), 21.1$ (s, $\left.\mathrm{NCCH}_{3}\right)$, $41.9\left(\mathrm{~s}, \mathrm{NCH}_{2} \mathrm{CH}_{2} \mathrm{~N}\right), 47.5\left(\mathrm{~s}, \mathrm{NCH}_{2} \mathrm{CH}_{3}\right), 53.8\left(\mathrm{~s}, \mathrm{NCH}_{2} \mathrm{CH}_{2} \mathrm{~N}\right)$, 93.1 (s, NCCCN), 127.6 (s, N-m- $\left.\left(\mathrm{CH}_{3}\right)_{3} C_{6} \mathrm{H}_{2}\right), 128.2$ (s, N-o-

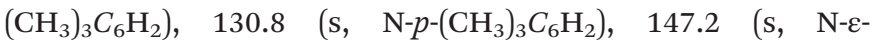
$\left.\left(\mathrm{CH}_{3}\right)_{3} \mathrm{C}_{6} \mathrm{H}_{2}\right), 155.3$ (s, NCCCN), 166.0 (s, NCCCN). HRMS $\left(\mathrm{FAB}^{+}\right) \mathrm{m} / \mathrm{z}[\mathrm{M}+\mathrm{H}]^{+}$calc. for $\mathrm{C}_{20} \mathrm{H}_{34} \mathrm{~N}_{3}$ : 316.2753; found 316.2750.

\section{Preparation of 2a}

A solution of $\left[\mathrm{NiCl}_{2}(2,4 \text {-lutidine })_{2}\right](1240 \mathrm{mg}, 3.61 \mathrm{mmol})$ in THF $(15 \mathrm{~mL})$ was prepared and cooled to $-78^{\circ} \mathrm{C}$. To this solution, a THF solution of the lithiated ligand (1a-Li), which was prepared by the reaction of $\mathbf{1 a}-\mathbf{H}(718 \mathrm{mg}, 3.62 \mathrm{mmol})$ with $n$-butyllithium $(1.40 \mathrm{~mL}$ of the $2.67 \mathrm{M}$ hexane solution, $3.74 \mathrm{mmol}$ ) at $-78{ }^{\circ} \mathrm{C}$, was added. The reaction mixture was allowed to warm to room temperature. After $18 \mathrm{~h}$, the volatiles were removed under reduced pressure. The residual solid was extracted with $\mathrm{CH}_{2} \mathrm{Cl}_{2}(30 \mathrm{~mL})$ and the volatiles were removed under reduced pressure. The resulting purple solid was washed with hexane and dried in vacuo to yield $2 a(1040 \mathrm{mg}$, $3.57 \mathrm{mmol}, 99 \%$ ). Analytically pure sample of $2 \mathrm{a}$ was obtained by recrystallization from $\mathrm{CH}_{2} \mathrm{Cl}_{2} /$ hexane. Anal. calc. for $\mathrm{C}_{11} \mathrm{H}_{21} \mathrm{ClN}_{2} \mathrm{NiO}$ : C, 45.33; H, 7.26; N, 9.61\%. Found: C, 45.35; $\mathrm{H}, 7.33 ; \mathrm{N}, 9.53 \% .{ }^{1} \mathrm{H}$ NMR $\left(\delta, \mathrm{CDCl}_{3}\right): 1.75\left(\mathrm{~s}, 3 \mathrm{H}, \mathrm{CH}_{3}\right), 1.78$ $\left(\mathrm{t}, J=7.2 \mathrm{~Hz}, 6 \mathrm{H}, \mathrm{NCH}_{2} \mathrm{CH}_{3}\right), 1.90\left(\mathrm{~s}, 3 \mathrm{H}, \mathrm{CH}_{3}\right), 2.14(\mathrm{t}, J=6.4$ $\left.\mathrm{Hz}, 2 \mathrm{H}, \mathrm{NCH}_{2} \mathrm{CH}_{2} \mathrm{~N}\right), 2.46\left(\mathrm{dq}, J=13.2,7.2 \mathrm{~Hz}, 2 \mathrm{H}, \mathrm{NCH}_{2} \mathrm{CH}_{3}\right)$, $3.06\left(\mathrm{t}, J=6.4 \mathrm{~Hz}, 2 \mathrm{H}, \mathrm{NCH}_{2} \mathrm{CH}_{2} \mathrm{~N}\right), 3.18(\mathrm{dq}, J=13.2,7.2 \mathrm{~Hz}$, $\left.2 \mathrm{H}, \mathrm{NCH}_{2} \mathrm{CH}_{3}\right), 4.92(\mathrm{~s}, 1 \mathrm{H}, \mathrm{CH}) .{ }^{13} \mathrm{C}\left\{{ }^{1} \mathrm{H}\right\} \operatorname{NMR}\left(\delta, \mathrm{CDCl}_{3}\right): 11.1$ (s, $\left.\mathrm{NCH}_{2} \mathrm{CH}_{3}\right), 21.2\left(\mathrm{~s}, \mathrm{CH}_{3}\right), 24.0\left(\mathrm{~s}, \mathrm{CH}_{3}\right), 50.2\left(\mathrm{~s}, \mathrm{NCH}_{2} \mathrm{CH}_{2} \mathrm{~N}\right)$, 52.0 (s, $\mathrm{NCH}_{2} \mathrm{CH}_{2} \mathrm{~N}+\mathrm{NCH}_{2} \mathrm{CH}_{3}$, overlapped), 99.6 (s, $\mathrm{CH}$ ), $164.6\left(\mathrm{~s}, \mathrm{CCH}_{3}\right), 176.8\left(\mathrm{~s}, \mathrm{CCH}_{3}\right)$.

\section{Preparation of $2 \mathbf{b}$}

Compound 1b-H (191 mg, $0.61 \mathrm{mmol}),\left[\mathrm{NiCl}_{2}\left(\mathrm{PPh}_{3}\right)_{2}\right]$ (405 mg, $0.62 \mathrm{mmol})$, and THF $(20 \mathrm{~mL})$ were mixed in a Schlenk tube. After stirring the reaction mixture for $1 \mathrm{~h}, \mathrm{NEt}_{3}(0.10 \mathrm{~mL}$, $73 \mathrm{mg}, 0.72 \mathrm{mmol}$ ) was added to the mixture and the solution was stirred for another $4 \mathrm{~h}$ at room temperature. Subsequently, 
the solution was filtered through a Celite pad and the filtrate was evaporated to dryness in vacuo. The residual solid was washed with $\mathrm{Et}_{2} \mathrm{O}$ and dried in vacuo to yield $\mathbf{2 b}$ as an orange solid (237 mg, $0.59 \mathrm{mmol}, 97 \%$ ). An analytically pure sample of $\mathbf{2 b}$ was obtained by recrystallization from $\mathrm{CH}_{2} \mathrm{Cl}_{2} /$ hexane. Anal. calc. for $\mathrm{C}_{19} \mathrm{H}_{21}$ ClNNiOP: C, 56.42; H, 5.23; N, 3.46\%. Found: $\mathrm{C}, 56.14 ; \mathrm{H}, 5.27 ; \mathrm{N}, 3.37 \% .{ }^{1} \mathrm{H}$ NMR $\left(\delta, \mathrm{C}_{6} \mathrm{D}_{6}\right): 1.27$ (dt, $\left.J=10.9,6.8 \mathrm{~Hz}, 2 \mathrm{H}, \mathrm{NCH}_{2} \mathrm{CH}_{2} \mathrm{P}\right), 1.35$ (s, 3H, $\left.\mathrm{NCCH}_{3}\right), 1.99$ (s, $3 \mathrm{H}, \mathrm{OCCH}_{3}$ ), 2.41 (dt, $\left.J=25.2,6.8 \mathrm{~Hz}, 2 \mathrm{H}, \mathrm{NCH}_{2} \mathrm{CH}_{2} \mathrm{P}\right), 4.92(\mathrm{~s}$, $1 \mathrm{H}, \mathrm{CH}), 6.98-7.08\left(\mathrm{~m}, 6 \mathrm{H}, \mathrm{P}-p-\mathrm{C}_{6} \mathrm{H}_{5}+\mathrm{P}-m-\mathrm{C}_{6} \mathrm{H}_{5}\right), 7.93-8.01$ $\left(\mathrm{m}, 4 \mathrm{H}, \mathrm{P}-o-\mathrm{C}_{6} \mathrm{H}_{5}\right) .{ }^{1} \mathrm{H}\left\{{ }^{31} \mathrm{P}\right\} \operatorname{NMR}\left(\delta, \mathrm{C}_{6} \mathrm{D}_{6}\right): 1.27(\mathrm{t}, J=6.7 \mathrm{~Hz}$, $\left.2 \mathrm{H}, \mathrm{NCH}_{2} \mathrm{CH}_{2} \mathrm{P}\right), 1.35\left(\mathrm{~s}, 3 \mathrm{H}, \mathrm{NCCH}_{3}\right), 1.99\left(\mathrm{~s}, 3 \mathrm{H}, \mathrm{OCCH}_{3}\right)$, $2.42\left(\mathrm{t}, J=6.7 \mathrm{~Hz}, 2 \mathrm{H}, \mathrm{NCH}_{2} \mathrm{CH}_{2} \mathrm{P}\right), 4.92$ (s, 1H, CH), 6.99-7.09 $\left(\mathrm{m}, 6 \mathrm{H}, \mathrm{P}-p-\mathrm{C}_{6} \mathrm{H}_{5}+\mathrm{P}-m-\mathrm{C}_{6} \mathrm{H}_{5}\right), 7.97(\mathrm{~d}, J=7.0 \mathrm{~Hz}, 4 \mathrm{H}$, P-o- $\left.\mathrm{C}_{6} \mathrm{H}_{5}\right) .{ }^{13} \mathrm{C}\left\{{ }^{1} \mathrm{H}\right\} \operatorname{NMR}\left(\delta, \mathrm{C}_{6} \mathrm{D}_{6}\right): 23.1\left(\mathrm{~s}, \mathrm{NCCH}_{3}\right), 25.2$ (d, $\left.{ }^{4} J_{\mathrm{PC}}=6.4 \mathrm{~Hz}, \mathrm{OCCH}_{3}\right), 30.6\left(\mathrm{~d},{ }^{1} J_{\mathrm{PC}}=25.7 \mathrm{~Hz}, \mathrm{NCH}_{2} \mathrm{CH}_{2} \mathrm{P}\right)$, $52.0\left(\mathrm{~d},{ }^{2} J_{\mathrm{PC}}=8.2 \mathrm{~Hz}, \mathrm{NCH}_{2} \mathrm{CH}_{2} \mathrm{P}\right), 99.8(\mathrm{~s}, \mathrm{OCCCN}), 128.7$ (d, $\left.{ }^{3} J_{\mathrm{PC}}=11.0 \mathrm{~Hz}, \mathrm{P}-m-\mathrm{C}_{6} \mathrm{H}_{5}\right), 129.6\left(\mathrm{~d},{ }^{1} J_{\mathrm{PC}}=52.2 \mathrm{~Hz}, \mathrm{P}-\varepsilon-\mathrm{C}_{6} \mathrm{H}_{5}\right)$, $131.1\left(\mathrm{~d},{ }^{4} J_{\mathrm{PC}}=2.7 \mathrm{~Hz}, \mathrm{P}-p-\mathrm{C}_{6} \mathrm{H}_{5}\right), 133.7\left(\mathrm{~d},{ }^{2} J_{\mathrm{PC}}=9.2 \mathrm{~Hz}\right.$, P-o- $\mathrm{C}_{6} \mathrm{H}_{5}$ ), 165.1 (s, OCCCN), 178.8 (d, ${ }^{3} \mathrm{~J}_{\mathrm{PC}}=2.7 \mathrm{~Hz}, \mathrm{OCCCN}$ ). ${ }^{31} \mathrm{P}\left\{{ }^{1} \mathrm{H}\right\} \operatorname{NMR}\left(\delta, \mathrm{C}_{6} \mathrm{D}_{6}\right): 37.5$.

\section{Preparation of $2 c$}

This complex was prepared from 1c-H (302 mg, $0.96 \mathrm{mmol}$ ), $\left[\mathrm{NiCl}_{2}(2,4 \text {-lutidine })_{2}\right](225 \mathrm{mg}, 0.65 \mathrm{mmol})$, and $\mathrm{NEt}_{3}(0.10 \mathrm{~mL}$, $73 \mathrm{mg}, 0.72 \mathrm{mmol})$ with THF $(10 \mathrm{~mL})$ as the solvent in the same manner as that described for $\mathbf{2 b}$. Complex $2 \mathbf{c}$ was isolated as a red solid (246 mg, $0.60 \mathrm{mmol}, 92 \%$ ). An analytically pure sample of $2 \mathrm{c}$ was obtained by recrystallization from $\mathrm{Et}_{2} \mathrm{O}$ / hexane. Anal. calc. for $\mathrm{C}_{20} \mathrm{H}_{32} \mathrm{ClN}_{3} \mathrm{Ni}$ : C, 58.79; $\mathrm{H}, 7.89 ; \mathrm{N}$, $10.28 \%$. Found: C, 58.48; H, 7.97; N, 10.12\%. ${ }^{1} \mathrm{H}$ NMR $(\delta$, $\left.\mathrm{CDCl}_{3}\right): 1.23\left(\mathrm{~s}, 3 \mathrm{H}, \mathrm{NCCH}_{3}\right), 1.67\left(\mathrm{t}, J=7.2 \mathrm{~Hz}, 6 \mathrm{H}, \mathrm{NCH}_{2} \mathrm{CH}_{3}\right)$, $1.92\left(\mathrm{~s}, 3 \mathrm{H}, \mathrm{NCCH}_{3}\right), 2.21\left(\mathrm{~s}, 3 \mathrm{H}, \mathrm{N}-p-\left(\mathrm{CH}_{3}\right)_{3} \mathrm{C}_{6} \mathrm{H}_{2}\right), 2.22(\mathrm{t}, J=$ $\left.6.4 \mathrm{~Hz}, 2 \mathrm{H}, \mathrm{NCH}_{2} \mathrm{CH}_{2} \mathrm{~N}\right), 2.46(\mathrm{dq}, J=12.8,7.2 \mathrm{~Hz}, 2 \mathrm{H}$, $\mathrm{NCH}_{2} \mathrm{CH}_{3}$ ), 2.49 (s, 6H, N-o- $\left.\left(\mathrm{CH}_{3}\right)_{3} \mathrm{C}_{6} \mathrm{H}_{2}\right), 3.25$ (dq, $J=12.8,7.2$ $\left.\mathrm{Hz}, 2 \mathrm{H}, \mathrm{NCH}_{2} \mathrm{CH}_{3}\right), 3.39\left(\mathrm{t}, J=6.4 \mathrm{~Hz}, 2 \mathrm{H}, \mathrm{NCH}_{2} \mathrm{CH}_{2} \mathrm{~N}\right), 4.56$ $(\mathrm{s}, 1 \mathrm{H}, \mathrm{CH}) \cdot 6.75\left(\mathrm{~s}, 2 \mathrm{H}, \mathrm{N}-m-\left(\mathrm{CH}_{3}\right)_{3} \mathrm{C}_{6} \mathrm{H}_{2}\right) \cdot{ }^{13} \mathrm{C}\left\{{ }^{1} \mathrm{H}\right\} \quad \mathrm{NMR}$ $\left(\delta, \mathrm{CDCl}_{3}\right): 11.2\left(\mathrm{~s}, \mathrm{NCH}_{2} \mathrm{CH}_{3}\right), 19.3\left(\mathrm{~s}, \mathrm{~N}-o-\left(\mathrm{CH}_{3}\right)_{3} \mathrm{C}_{6} \mathrm{H}_{2}\right), 21.0$ (s, N-p-( $\left.\left(\mathrm{H}_{3}\right)_{3} \mathrm{C}_{6} \mathrm{H}_{2}\right), 22.8\left(\mathrm{~s}, \mathrm{NCCH}_{3}\right), 23.4\left(\mathrm{~s}, \mathrm{NCCH}_{3}\right), 49.9$ (s, $\left.\mathrm{NCH}_{2} \mathrm{CH}_{2} \mathrm{~N}\right), 51.3\left(\mathrm{~s}, \mathrm{NCH}_{2} \mathrm{CH}_{3}\right), 52.1\left(\mathrm{~s}, \mathrm{NCH}_{2} \mathrm{CH}_{2} \mathrm{~N}\right)$, $99.3(\mathrm{~s}, \mathrm{NCCCN}), 127.8$ (s, N-m- $\left.\left(\mathrm{CH}_{3}\right)_{3} C_{6} \mathrm{H}_{2}\right), 132.7$ (s, N-o$\left.\left(\mathrm{CH}_{3}\right)_{3} C_{6} \mathrm{H}_{2}\right), \quad 133.2 \quad\left(\mathrm{~s}, \quad \mathrm{~N}-p-\left(\mathrm{CH}_{3}\right)_{3} C_{6} \mathrm{H}_{2}\right), \quad 149.1 \quad$ (s, N- $\varepsilon-$ $\left(\mathrm{CH}_{3}\right)_{3} C_{6} \mathrm{H}_{2}$ ), 157.7 (s, NCCCN), 158.0 (s, NCCCN).

\section{Typical procedure for the cross-coupling reaction (Table 2,} entry 15): GLC analysis

Complex 2b (10.2 mg, $0.025 \mathrm{mmol}$ ), octadecane (145.8 mg, $0.57 \mathrm{mmol}$ ), THF (5 mL), and 4-chlorotoluene (130.1 mg, $0.122 \mathrm{~mL}, 1.03 \mathrm{mmol}$ ) were placed in a Schlenk tube. Phenylmagnesium bromide $(1.5 \mathrm{~mL}$ of the $1.0 \mathrm{M}$ THF solution, $1.5 \mathrm{mmol}$ ) was added at once to the reaction mixture. After stirring for $24 \mathrm{~h}$ at $25{ }^{\circ} \mathrm{C}, 1 \mathrm{M}$ hydrochloric acid $(5 \mathrm{~mL})$ was added to quench the reaction. The products were extracted with $\mathrm{Et}_{2} \mathrm{O}$ and the yields of the products were determined by GLC analysis using octadecane as an internal standard.

\section{Conflicts of interest}

There are no conflicts of interest to declare.

\section{Acknowledgements}

The authors are grateful to Prof. Masatoshi Asami (Yokohama Natl. Univ.) for fruitful discussions. We thank Dr Takahiro Iwamoto and Prof. Masaharu Nakamura (Kyoto Univ.) for their kind help in the HRMS measurements, Dr Tomoyo Misawa (Sophia Univ.) for her kind help in the CV measurements, and Mr Kei Funatsu (Yokohama Natl. Univ.) for experimental assistance. This work was supported by JSPS KAKENHI Grant Numbers 25410063 and JP17K05805. This work was also supported by the Collaborative Research Program of Institute for Chemical Research, Kyoto University (grant number 2017-20). The computations were performed using the Research Center for Computational Science, Okazaki, Japan.

\section{Notes and references}

1 (a) K. Tamao, K. Sumitani and M. Kumada, J. Am. Chem. Soc., 1972, 94, 4374-4376; (b) R. J. P. Corriu and J. P. Masse, J. Chem. Soc., Chem. Commun., 1972, 144.

2 Review articles: (a) Cross-Coupling Reactions: A Practical Guide, ed. N. Miyaura, Springer-Verlag, Berlin, Heidelberg, 2002; (b) Metal-Catalyzed Cross-Coupling Reactions, ed. A. de Meijere and F. Diederich, Wiley-VCH Verlag GmbH \& Co. KGaA, Weinheim, 2nd edn, 2004; (c) A. F. Littke and G. C. Fu, Angew. Chem., Int. Ed., 2002, 41, 4176-4211; (d) A. C. Frisch and M. Beller, Angew. Chem., Int. Ed., 2005, 44, 674-688; (e) J.-P. Corbet and G. Mignani, Chem. Rev., 2006, 106, 2651-2710; $(f)$ J. Terao and N. Kambe, Acc. Chem. Res., 2008, 41, 1545-1554; (g) X. Hu, Chem. Sci., 2011, 2, 1867-1886; (h) R. Jana, T. P. Pathak and M. S. Sigman, Chem. Rev., 2011, 111, 1417-1492.

3 (a) K. Tamao, A. Minato, N. Miyake, T. Matsuda, Y. Kiso and M. Kumada, Chem. Lett., 1975, 133-136; (b) V. P. W. Böhm, T. Weskamp, C. W. K. Gstöttmayr and W. A. Herrmann, Angew. Chem., Int. Ed., 2000, 39, 16021604; (c) G. Y. Li and W. J. Marshall, Organometallics, 2002, 21, 590-591; (d) L. Ackermann, R. Born, J. H. Spatz and D. Meyer, Angew. Chem., Int. Ed., 2005, 44, 7216-7219; (e) L. Ackermann, R. Born, J. H. Spatz, A. Althammer and C. J. Gschrei, Pure Appl. Chem., 2006, 78, 209-214; $(f)$ D. Sémeril, M. Lejeune, C. Jeunesse and D. Matt, J. Mol. Catal. A: Chem., 2005, 239, 257-262; $(g)$ L. Monnereau, D. Sémeril and D. Matt, Chem. Commun., 2011, 47, 66266628; (h) N. Şahin, H. El Moll, D. Sémeril, D. Matt, İ. Özdemir, C. Kaya and L. Toupet, Polyhedron, 2011, 30, 2051-2054; (i) N. Şahin, D. Sémeril, E. Brenner, D. Matt, İ. Özdemir, C. Kaya and L. Toupet, Eur. J. Org. Chem., 2013, 4443-4449; $(j)$ K. Matsubara, K. Ueno and Y. Shibata, Organometallics, 2006, 25, 3422-3427; (k) Z. Xi, B. Liu and 
W. Chen, J. Org. Chem., 2008, 73, 3954-3957; (l) N. Yoshikai, H. Matsuda and E. Nakamura, J. Am. Chem. Soc., 2009, 131, 9590-9599; ( $m$ ) T. Hatakeyama, S. Hashimoto, K. Ishizuka and M. Nakamura, J. Am. Chem. Soc., 2009, 131, 11949-11963; (n) J. Berding, T. F. van Dijkman, M. Lutz, A. L. Spek and E. Bouwman, Dalton Trans., 2009, 6948-6955; (o) R. Ghosh and A. Sarkar, J. Org. Chem., 2010, 75, 8283-8286; (p) F. Li, J. J. Hu, L. L. Koh and T. S. A. Hor, Dalton Trans., 2010, 39, 5231-5241; (q) M. J. Iglesias, A. Prieto and M. C. Nicasio, Org. Lett., 2012, 14, 4318-4321; (r) S. G. Rull, R. J. Rama, E. Álvarez, M. R. Fructos, T. R. Belderrain and M. C. Nicasio, Dalton Trans., 2017, 46, 7603-7611; (s) I. Stamatopoulos, M. Plaček, V. Psycharis, A. Terzis, J. Svoboda, P. Kyritsis and J. Vohlidíal, Inorg. Chim. Acta, 2012, 387, 390-395; $(t)$ Z. Jin, Y.-J. Li, Y.-Q. Ma, L.-L. Qiu and J.-X. Fang, Chem. - Eur. J., 2012, 18, 446-450; (u) J. Guo, L. Lv, X. Wang, C. Cao, G. Pang and Y. Shi, Inorg. Chem. Commun., 2013, 31, 74-78; (v) Y.-C. Xu, J. Zhang, H.-M. Sun, Q. Shen and Y. Zhang, Dalton Trans., 2013, 42, 8437-8445; (w) J. Zhang, J. Xu, Y. Xu, H. Sun, Q. Shen and Y. Zhang, Organometallics, 2015, 34, 5792-5800; (x) J. Zhang, G. Lu, J. Xu, H. Sun and Q. Shen, Org. Lett., 2016, 18, 2860-2863; (y) M.-T. Chen, W.-Y. Lee, T.-L. Tsai and L.-C. Liang, Organometallics, 2014, 33, 5852-5862; (z) Ł. Banach, P. A. Guńka and W. Buchowicz, Dalton Trans., 2016, 45, 8688-8692.

4 Review articles: (a) M. E. van der Boom and D. Milstein, Chem. Rev., 2003, 103, 1759-1792; (b) H. Nishiyama, Chem. Soc. Rev., 2007, 36, 1133-1141; (c) P. Bhattacharya and H. Guan, Comments Inorg. Chem., 2011, 32, 88-112; (d) J. Choi, A. H. R. MacArthur, M. Brookhart and A. S. Goldman, Chem. Rev., 2011, 111, 1761-1779; (e) N. Selander and K. J. Szabó, Chem. Rev., 2011, 111, 2048-2076; $(f)$ J.-L. Niu, X.-Q. Hao, J.-F. Gong and M.-P. Song, Dalton Trans., 2011, 40, 5135-5150; (g) S. Schneider, J. Meiners and B. Askevold, Eur. J. Inorg. Chem., 2012, 412-429; (h) M. Asay and D. Morales-Morales, Dalton Trans., 2015, 44, 17432-17447.

5 Review articles: (a) R. A. Gossage, L. A. van de Kuil and G. van Koten, Acc. Chem. Res., 1998, 31, 423-431; (b) M. Albrecht and G. van Koten, Angew. Chem., Int. Ed., 2001, 40, 3750-3781; (c) J. T. Singleton, Tetrahedron, 2003, 59, 1837-1857; (d) L.-C. Liang, Coord. Chem. Rev., 2006, 250, 1152-1177; (e) The Chemistry of Pincer Compounds, ed. D. Morales-Morales and C. M. Jensen, Elsevier, Amsterdam, 2007; $(f)$ D. Benito-Garagorri and K. Kirchner, Acc. Chem. Res., 2008, 41, 201-213; (g) Z.-X. Wang and N. Liu, Eur. J. Inorg. Chem., 2012, 901-911; (h) Top. Organomet. Chem., in Organometallic Pincer Chemistry, ed. G. van Koten and D. Milstein, Springer, Berlin, 2013, vol. 40; (i) Pincer and Pincer-Type Complexes: Applications in Organic Synthesis and Catalysis, ed. K. J. Szabó and O. F. Wendt, Wiley-VCH Verlag GmbH \& Co. KGaA, Weinheim, 2014; (j) S. Murugesan and K. Kirchner, Dalton Trans., 2016, 45, 416-439.

6 K. Inamoto, J.-I. Kuroda, K. Hiroya, Y. Noda, M. Watanabe and T. Sakamoto, Organometallics, 2006, 25, 3095-3098.
7 (a) L.-C. Liang, P.-S. Chien, J.-M. Lin, M.-H. Huang, Y.-L. Huang and J.-H. Liao, Organometallics, 2006, 25, 13991411; (b) L.-C. Liang, W.-Y. Lee, Y.-T. Hung, Y.-C. Hsiao, L.-C. Cheng and W.-C. Chen, Dalton Trans., 2012, 41, 13811388.

8 (a) Z.-X. Wang and L. Wang, Chem. Commun., 2007, 2423-2425; (b) Z.-X. Wang and Z.-Y. Chai, Eur. J. Inorg. Chem., 2007, 4492-4499; (c) K. Sun, L. Wang and Z.-X. Wang, Organometallics, 2008, 27, 5649-5656; (d) C. Zhang and Z.-X. Wang, Organometallics, 2009, 28, 6507-6514; (e) L.-G. Xie and Z.-X. Wang, Chem. - Eur. J., 2010, 16, 10332-10336; $(f)$ N. Liu and Z.-X. Wang, J. Org. Chem., 2011, 76, 10031-10038; (g) W.-J. Guo and Z.-X. Wang, J. Org. Chem., 2013, 78, 1054-1061; (h) X.-Q. Zhang and Z.-X. Wang, Synlett, 2013, 2081-2084; (i) D. Wu and Z.-X. Wang, Org. Biomol. Chem., 2014, 12, 6414-6424.

9 (a) Z. Csok, O. Vechorkin, S. B. Harkins, R. Scopelliti and X. Hu, J. Am. Chem. Soc., 2008, 130, 8156-8157; (b) O. Vechorkin, A. Godinat, R. Scopelliti and X. Hu, Angew. Chem., Int. Ed., 2011, 50, 11777-11781; (c) J. Breitenfeld, J. Ruiz, M. D. Wodrich and X. Hu, J. Am. Chem. Soc., 2013, 135, 12004-12012; (d) J. Breitenfeld, M. D. Wodrich and X. Hu, Organometallics, 2014, 33, 57085715; (e) P. M. P. Garcia, T. D. Franco, A. Epenoy, R. Scopelliti and X. Hu, ACS Catal., 2016, 6, 258-261; (f) T. D. Franco, M. Stojanovic, S. C. Keller, R. Scopelliti and X. Hu, Helv. Chim. Acta, 2016, 99, 830-847.

10 (a) Y. Zhou, Z. Xi, W. Chen and D. Wang, Organometallics, 2008, 27, 5911-5920; (b) S. Gu and W. Chen, Organometallics, 2009, 28, 909-914; (c) A. Liu, X. Zhang and W. Chen, Organometallics, 2009, 28, 4868-4871; (d) C. Chen, H. Qiu and W. Chen, J. Organomet. Chem., 2012, 696, 4166-4172.

11 (a) M. Shen, P. Hao and W.-H. Sun, J. Organomet. Chem., 2008, 693, 1683-1695; (b) J. Sanford, C. Dent, J. D. Masuda and A. Xia, Polyhedron, 2011, 30, 1091-1094.

12 (a) G. T. Venkanna, T. V. M. Ramos, H. D. Arman and Z. J. Tonzetich, Inorg. Chem., 2012, 51, 12789-12795; (b) G. T. Venkanna, S. Tammineni, H. D. Arman and Z. J. Tonzetich, Organometallics, 2013, 32, 4656-4663.

13 (a) Y. Sun, X. Li and H. Sun, Dalton Trans., 2014, 43, 94109413; (b) Y. Sun, X. Li and H. Sun, Inorg. Chim. Acta, 2014, 415, 95-97.

14 (a) A. Castonguay, A. L. Beauchamp and D. Zargarian, Organometallics, 2008, 27, 5723-5732; (b) Y. Zhang, G. Song, G. Ma, J. Zhao, C.-L. Pan and X. Li, Organometallics, 2009, 28, 3233-3238; (c) M. M. Tamizh and R. Karvembu, Inorg. Chem. Commun., 2012, 25, 30-34; (d) V. Kuchtanin, L. Kleščíková, M. Šoral, R. Fischer, Z. Růžičková, E. Rakovský, J. Moncol' and P. Segl'a, Polyhedron, 2016, 117, 90-96; (e) M. Mastalir and K. Kirchner, Monatsh. Chem., 2017, 148, 105-109; (f) A. G. Nair, R. T. McBurney, M. R. D. Gatus, D. B. Walker, M. Bhadbhade and B. A. Messerle, J. Organomet. Chem., 2017, 845, 63-70; $(g)$ P. Hasche, M. Joksch, 
G. Vlachopoulou, H. Agarwala, A. Spannenberg and T. Beweries, Eur. J. Inorg. Chem., 2018, 676-680.

15 Although this ligand is often described as " $\beta$-ketiminato" in other manuscripts, we consider it to be an anionic ligand derived from $\beta$-aminoketone 1. Therefore, we have used the term ' $\beta$-aminoketonato' to refer to this ligand in our paper.

16 Y. Yamaguchi, H. Ando, M. Nagaya, H. Hinago, T. Ito and M. Asami, Chem. Lett., 2011, 40, 983-985.

17 (a) H. Hinago, Y. Shidara, T. Sato, Y. Yamaguchi and T. Ito, Kobunshi Ronbunshu, 2011, 68, 484-492; (b) T. Sakayori, T. Sato, M. Nagaya, T. Yamaguchi, S. Ishihara, T. Kaneko and Y. Yamaguchi, Kobunshi Ronbunshu, 2015, 72, 306-317.

18 K. Hiraki, T. Masumoto, Y. Fuchita and Y. Zegi, Bull. Chem. Soc. Jpn., 1981, 54, 1044-1047.
19 R. Taylor, O. Kennard and W. Versichel, Acta Crystallogr., Sect. B: Struct. Sci., 1984, 40, 280-288.

20 J. F. Hartwig, in Organotransition Metal Chemistry from Bonding to Catalysis, University Science Books, Mill Valley, California, 2010, ch. 6.1.

21 D. Spasyuk and D. G. Gusev, Organometallics, 2012, 31, 5239-5242.

22 (a) D. V. Vitanova, F. Hampel and K. C. Hultzsch, J. Organomet. Chem., 2005, 690, 5182-5197; (b) D. M. Granum, P. J. Riedel, J. A. Crawford, T. K. Mahle, C. M. Wyss, A. K. Begej, N. Arulsamy, B. S. Pierce and M. P. Mehn, Dalton Trans., 2011, 40, 5881-5890.

23 H. L. Wiencko, E. Kogut and T. H. Warren, Inorg. Chim. Acta, 2003, 345, 199-208.

24 L. M. Venanzi, J. Chem. Soc., 1958, 719-724. 